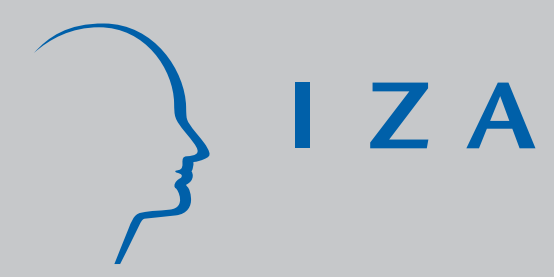

IZA DP No. 861

Inflation, Minimum Wage and Other Wages:

An Econometric Study on French

Macroeconomic Data

Yannick L'Horty

Christophe Rault

August 2003 


\title{
Inflation, Minimum Wage and Other Wages: An Econometric Study on French Macroeconomic Data
}

\author{
Yannick L'Horty \\ EPEE, University of Evry Val d'Essonne \\ Christophe Rault \\ EPEE, University of Evry Val d'Essonne, \\ EUREQua, Sorbonne University and IZA Bonn
}

\author{
Discussion Paper No. 861 \\ August 2003
}

\author{
IZA \\ P.O. Box 7240 \\ D-53072 Bonn \\ Germany \\ Tel.: +49-228-3894-0 \\ Fax: +49-228-3894-210 \\ Email: iza@iza.org
}

\begin{abstract}
This Discussion Paper is issued within the framework of IZA's research area Mobility and Flexibility of Labor. Any opinions expressed here are those of the author(s) and not those of the institute. Research disseminated by IZA may include views on policy, but the institute itself takes no institutional policy positions.

The Institute for the Study of Labor (IZA) in Bonn is a local and virtual international research center and a place of communication between science, politics and business. IZA is an independent, nonprofit limited liability company (Gesellschaft mit beschränkter Haftung) supported by Deutsche Post World Net. The center is associated with the University of Bonn and offers a stimulating research environment through its research networks, research support, and visitors and doctoral programs. IZA engages in (i) original and internationally competitive research in all fields of labor economics, (ii) development of policy concepts, and (iii) dissemination of research results and concepts to the interested public. The current research program deals with (1) mobility and flexibility of labor, (2) internationalization of labor markets, (3) welfare state and labor market, (4) labor markets in transition countries, (5) the future of labor, (6) evaluation of labor market policies and projects and (7) general labor economics.
\end{abstract}

IZA Discussion Papers often represent preliminary work and are circulated to encourage discussion. Citation of such a paper should account for its provisional character. A revised version may be available on the IZA website (www.iza.org) or directly from the author. 


\section{ABSTRACT \\ Inflation, Minimum Wage and Other Wages: An Econometric Study on French Macroeconomic Data*}

This paper examines the set of interdependences between the formation of wages, prices and the minimum wage (SMIC) through a vectorial error correction model estimated on French quarterly macroeconomic data covering the 1970-1/1999-4 period. Two periods are distinguished: the period of inflation rise from 1970 to 1981, which coincides with an important squeeze of the wage range, measured by the ratio of the minimum wage to the hourly wage rate; the period of disinflation since 1981, that has been concomitant with a stability of wage inequalities. Disinflation has hardly benefited the evolution of the SMIC which has always profited by price rises, in real and relative terms, which have become less strong. This evolution doesn't benefit any more of wage rises, when the interdependences between variables are taken into account. The SMIC seems however to have gained in efficiency as an instrument of wage disparity reduction. Its rises are finally more persistent in real terms and relatively to the other salaries and have always as little inflationary impact on wages as on prices.

JEL Classification: $\quad$ C32, E31, J31, J38

Keywords: $\quad$ wage formation, minimum wage, error correction model, cointegration, impulse analysis

Corresponding author:

Christophe Rault

Department of Economics

University of Evry Val d'Essonne

4bd. François Mitterrand

91025 Evry cedex

France

Email: chrault@hotmail.com

\footnotetext{
* Financial support from the French Labour Ministry through the research program "emplois flexibles, salaries rigides" is gratefully acknowledged.
} 


\section{Introduction}

Whereas the effects of minimum wage on employment have been the subject of many papers both theoretical and empirical, the related question of its consequences on price formation and other wages has been relatively unexplored in literature. One will thus look vainly for references about the minimum wage impact on other wages, or prices in recent works taking stock of economic studies on minimum wage (Dolado and alii,1996; OECD, 1998). However when the interdependences between variables are taken into account, this omission can appear detrimental. On the one hand, minimum wage effects on inflation have consequences on the employment level. On the other, SMIC effects on other wages are crucial if one wishes to assess the redistributive impact of minimum wage rises.

Besides, the rare applied works which deal with the inflationary effects of the SMIC are based on estimations of wage equations carried out on macro-economic data using univariate econometric techniques. Minimum wage is with the consumer price index one of the explanatory variables of the average wage increases but interdependences between these three variables are not taken into account, while it is obvious that minimum wage is determined institutionally by wages and inflation. This approach is particularly used by the French Ministry of Finances Forecast Department or by the French Labour Ministry (cf. CSERC, 1999 for a survey) as well as by the OFCE (cf. Chauvin and Heyer, 2001, for an illustration).

In this context, the aim of this paper is to examine the set of interdependences between the formation of wages, prices and the minimum wage (SMIC). Our approach is essentially empirical. We don't make any a priori assumption on the relationships between these three variables and we estimate a vectorial error correction model (VAR-ECM) on French quarterly macroeconomic data covering the 1970-1/1999-4 period. 
In a first stage, we conduct stationarity tests on the series of consumption price index (ipc), SMIC (smic), and workers' hourly wage rate. Then, in a second one we investigate the existence of cointegrating relationships between these variables and we look for an econometric specification in accordance with the statistical properties of the three series. Finally, we study the interdependences between these three variables through causality tests as well as an impulse analysis by calculating the variance decompositions (VDCs) of forecast error and impulse response functions (IRFs) to shocks, in a VAR-ECM model.

The rest of the paper is organised as follows. In Section 1 a brief review of economic and institutional causalities between the minimum wage, other wages and inflation is provided to motivate the empirical analysis. Section 2 reports the model estimates and section 3 explores the actual (effective) causalities and the long term effects of shocks on the three variables.

\section{Economic and institutional causalities}

The set of causalities between minimum wage, other wages and inflation are depicted on the diagram below. The 1 and 2 relations correspond to the institutional mechanisms of SMIC indexation on wages and prices. In return, the SMIC is likely to have an influence on wage formation (3) and on prices (6) which are themselves linked (4 and 5 relations).

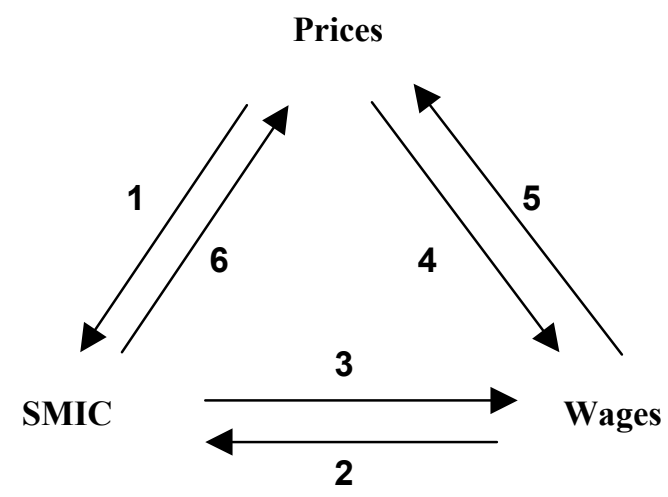




\section{The SMIC institutional indexation on wages and prices}

Since the law of January 2, 1970 which turned the guaranteed interprofessional minimum wage (SMIG) into growth minimum wage (SMIC), the minimum wage has been indexed both on prices and on the average wage. The aim of the lawmaker was to exclude « any durable distortion between the increase of the growth minimum wage and the evolution of general economic conditions and income» (article. L-114-6 of the Labour Code). However if the indexation to prices is guaranteed, the automatic indexation to wages is only partial. It can be reached in the medium-term by discretionary rises (often described as set of hikes given to the SMIC) which traditionally happened on July 1.

- As regards the indexation of the SMIC on prices, the benchmark is the consumer price index (excluding tobacco since the 1992 law). Starting from the previous minimum wage hike, it is necessary that the accumulated increase of this index should exceed $2 \%$ to be changed. In this case this rise occurs as early as the following day of the publication of the index every month. As a consequence, indexation is very fast in a period of strong inflation and slower in a period of low one. That is the reason why the SMIC has experienced an increase in stages since 1987 whereas it was more regular before.

- Beyond this purchasing power stability guarantee, the 1970 law indicates that in any case « the SMIC annual purchasing power increase cannot be smaller than half of that of average hourly wages» (article. L 141-5). The benchmark index is the workers 'hourly wage rate (TSH) ' which is provided by the ACEMO survey carried out quarterly by the French Ministry of Labour. If the wage rate annually rises by $6 \%$ and inflation by $3 \%$, the SMIC guaranteed increase will thus be of $4,5 \%$. This half indexation to TSH is the result of a compromise between a complete indexation (whose inflationist effects were dreaded) and an absence of indexation which was likely to promote relative wage inequalities (as it was the case with the SMIG). 
To reach this mid-term objective of relative wage stability, the law permits besides the possibility of annual hikes taking place on July 1 within the framework of a decree adopted by the Cabinet, following the advice of the national commission on joint bargaining.

This «discretionary » hike is not included in the clause on indexation to the TSH and thus doesn't penalize the coming SMIC rises. This is no more the case if this increase takes place at other dates than on July 1 (which requires in any other cases the advice of the national commission on joint bargaining).

\section{An imperfect indexation in practice}

For some reasons due to index availability and institutional mechanisms, the SMIC indexation to prices and even more to wages is thus neither instantaneous nor complete. Actually two periods must be distinguished. From the early seventies up to the SMIC hike in May 1981, the minimum wage increase has been globally much higher than that of prices and wages. On the contrary, since June 1981, the minimum wage moderation has coincided with numerous episodes of SMIC underindexation.

- In relation to prices, as indexation is slower when inflation is low, one can count numerous episodes when prices have actually risen faster that the SMIC : It has been the case for 8 quarters since 1970 if one refers to the SMIC annual growth of rate, and for 56 quarters if one considers the SMIC quarterly growth (on a total of 120 between 1970 and 2000). These situations have become more frequent in the eighties and still more in the nineties with continuous inflation control.

- In relation to wages, the SMIC indexation is not automatic and is in practice still more imperfect. One can thus counts 58 quarters (out of 117) when the annual SMIC increase is lower than that of TSH (see table 1). As far as the indexation to half of TSH upgrade is concerned, it is also neither automatic, since it doesn't occur when the TSH growth is smaller 
than that of prices (which happened four times in annual progression in the eighties), nor instantaneous (since the adjustment happened most often on July 1). One thus counts 6 quarters when the annual SMIC growth has been smaller than that of half of TSH and 47 quarters for the quarterly growth.

Table 1 - The SMIC imperfect indexation to wages and prices

\begin{tabular}{|c|c|c|}
\hline Number of quarters when the SMIC... & $\begin{array}{l}\text { Annual } \\
\text { growth of rate }\end{array}$ & $\begin{array}{l}\text { Quarterly } \\
\text { growth of rate }\end{array}$ \\
\hline has less risen than 'IPC & 8 & 56 \\
\hline has less risen than TSH & 58 & 69 \\
\hline has less risen than half of TSH & 6 & 47 \\
\hline on a total of & 117 & 120 \\
\hline
\end{tabular}

Fields : quarterly data between 1970-1 and 2000-1

All in all, the SMIC increase is clearly higher than that of prices (see graph 1). The minimum wage purchasing power has thus been multiplied by 2.3 since 1970 , almost by 1.8 before 1981 . In relation to wages, this report is variable according to the periods. Up to the early eighties the SMIC increase was much more important than that of TSH. Between 1970 and 1981, the SMIC rose $20 \%$ more than the TSH (almost half of this increase comes from the 1981 hike), thus filling up the gap created between the SMIC increase and wages between 1950 and 1970. Since the 1981 upgrade, on the contrary, the ratio of SMIC to TSH has remained approximately stable according to the principle of the 1970 law.

Graph 1 - SMIC, inflation and wage growth since 1970

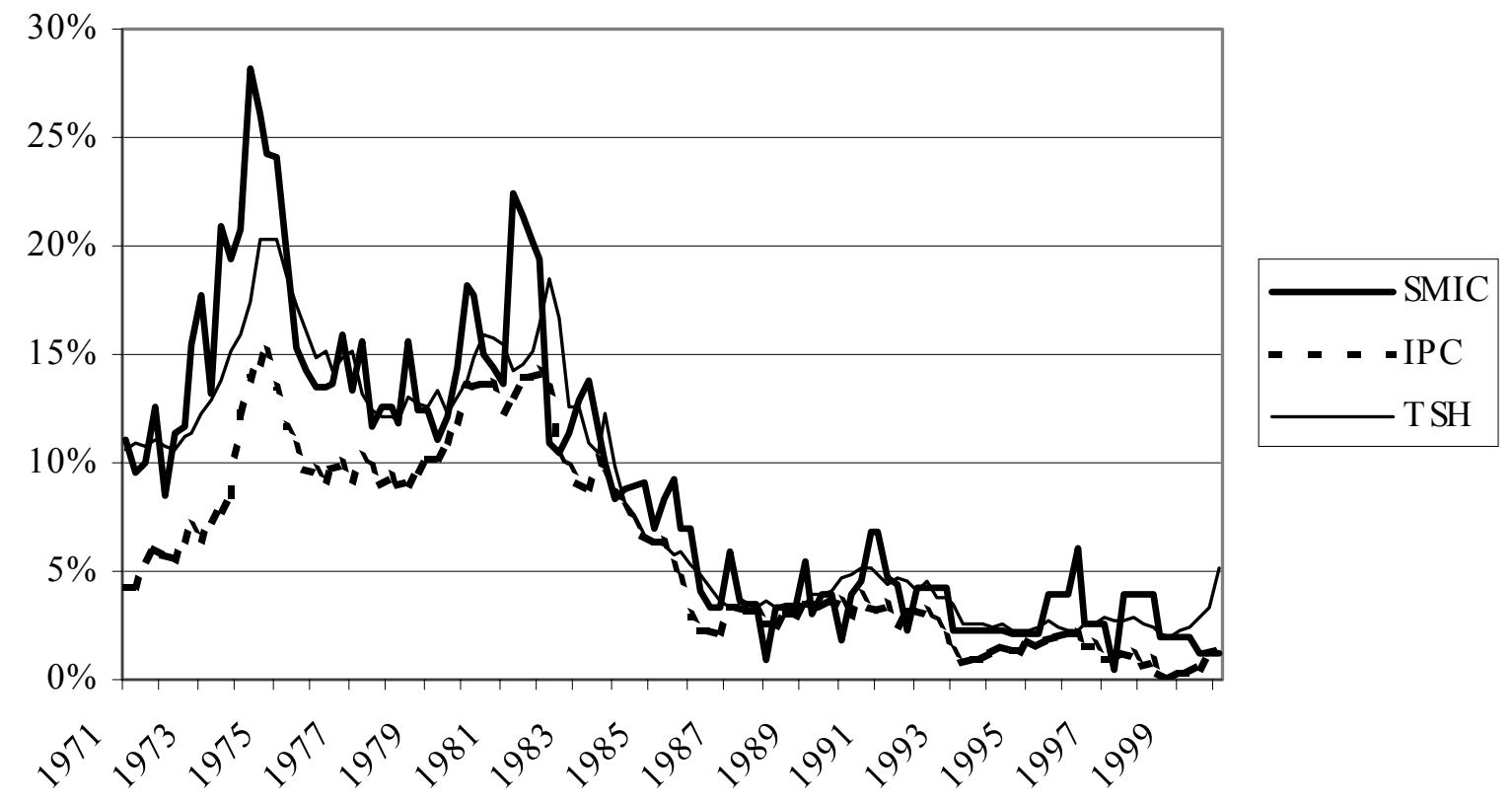




\section{The economic relationships : feedbacks from the SMIC to wages and prices}

The third relationship is the one that goes from minimum wage to other wages. Minimum wage has a positive effect on the average wage according to the univariate estimations of wage equations carried out by the French Ministry of Finances Forecast Department or by the French Labour Ministry on French time series (see CSERC, 1999, for a survey of these studies). To justify this relation a former argument is given by the accounting impact on the average wage which corresponds to the share of SMIC employees in the whole category of employees . A latter argument is connected to a very well documented truncation effect in applied works: if individual productivities are given and if wages are equal to these productivities, the effect of the minimum wage is to truncate the "natural » wage distribution (Stigler, 1946). A minimum wage rise thus leads to an average wage increase by making jobs vanish whose wages are under the new minimum. A third argument is that of the diffusion effect and it is related to the other wage formation. Those wages increase with the minimum wage if they are negotiated and if the minimum wage plays a benchmark role in this bargaining (for instance if it constitutes a point of withdrawal or if employees are sensitive to relative earning differences, Grossman, 1983).

This positive relationship can be put into question when one considers the set of interdependences between the SMIC and the other wages. If a minimum wage increase raises unskilled labour cost (spreading effect) and reduces the employment of these employees (truncation effect), it will also lead to substitution effects with the other employee categories and to volume or scale effects. A minimum wage increase is a rise of production factor cost and the effect on other costs depends on the crossed price elasticities which are a priori unknown. If substitution effects are higher than volume effects, other employee employment and their wages will rise. On the contrary if substitution effects are smaller than volume effects, a minimum wage increase will reduce other employee employment as 
well as their wages. We find again then the classical result of input price frontier : if the price of an input increases, prices of other factors must decrease. All in all the effects of minimun wage are a priori of undetermined sign when one considers the set of interdependences between these variables.

The other theoretical relationships present, less ambiguity. The relations between wages and prices (relations 4 and 5) correspond to the wage and price spiral and are a priori positive. A price increase is passed on wages by wage bargaining. A wage rise leads to an upward pressure on prices, which is strictly proportional if margin behaviours remain unchanged. Likewise minimum wage exerts a positive effect on prices (relation 6). A minimum wage rise, like a rise of other wages, increases production costs, which leads to an increase of prices strictly proportional to the share of SMIC employees in the set of production costs if margins are unchanged.

\section{Econometric modelling}

The aim of this study is to examine and quantify the set of interdependences between the SMIC, inflation, and the formation of wages. Our approach is essentially empirical. We « let the data speak for themselves » by estimating a vectorial error correction model (VAR-ECM), i.e. without imposing any a priori assumption on the relationships between these three variables.

The set of estimations are carried out using French quarterly macroeconomic data covering the 19701/1999-4 period. Three series are used : the consumer price index (ipc), the SMIC nominal level (smic) and workers 'hourly wage rate $(t s h)$. The graphs of series are given in appendix 2 .

\section{Integration degree of the series and structural break in 1981}

We shall report in this sub-section the results of conventional unit-root tests. Indeed, the analysis first step is simply to look at the data univariate properties and to determine their integratedness degree. 
Theoretically a process is either I(0), I(1) or I(2). Nevertheless in practice many variables or variable combinations are bordeline cases, so that distinguishing between a strongly autoregressive I( 0$)$ or I(1) process (interest rates are a typical example), between a strongly autoregressive I(1) or I(2) process (nominal prices are a typical example) is far from being easy. We have therefore applied a sequence of standard time series unit root tests (Schmidt and Phillips' test, 1992, Kwiatkowsky, Phillips and Shin 's test (KPSS, 1992, and the efficient unit-root tests suggested by Elliott, Rothenberg and Stock, 1996) to investigate which of the $\mathrm{I}(0), \mathrm{I}(1), \mathrm{I}(2)$ assumption is most likely to hold ${ }^{1}$. The results of these unit-root tests, not reported here to save space ${ }^{2}$, are concomitant and indicate that the unit-root null hypothesis cannot be rejected at the $5 \%$ level for the three series under consideration. We have also applied the three tests on the variables taken in first differences and we find evidence in favour of the rejection of the non-stationary hypothesis for all series. This leads us to conclude that our three series are well characterised as an I(1) process, some with non-zero drift as TSH for instance.

The next step of the analysis requires the estimation of the non-constraint model. Before choosing this model we have made many prior estimations which have proved to be unsatisfactory. In particular, it has turned out inadequate to specify a unique model statistically acceptable for all the period considered (1970-1/1999-4), because the estimated parameters showed a strong instability in the eighties. The model re-estimation by recursive least squares until $1999: 4$ and the implementation of Chow tests have enabled us to determine precisely the date of the structural break which is in the second quarter of 1981 (see graph 2).

\footnotetext{
${ }^{1}$ These tests are sufficiently well-known to exempt us from a formal presentation of them and for detailed discussions the reader will find references at the end of the paper.

${ }^{2}$ They are available upon request.
} 


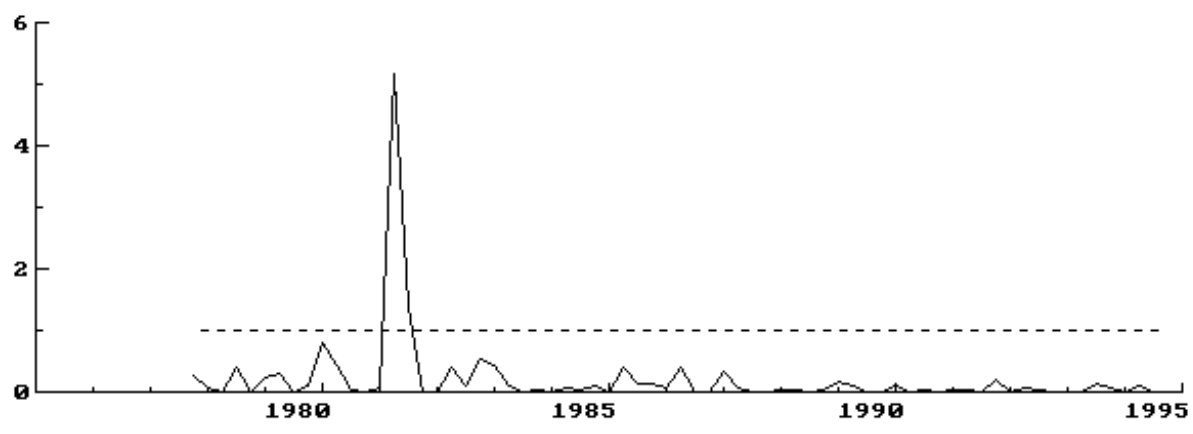

$1 \uparrow$ CHOWs $=$

$5 \% \operatorname{crit}=\ldots$

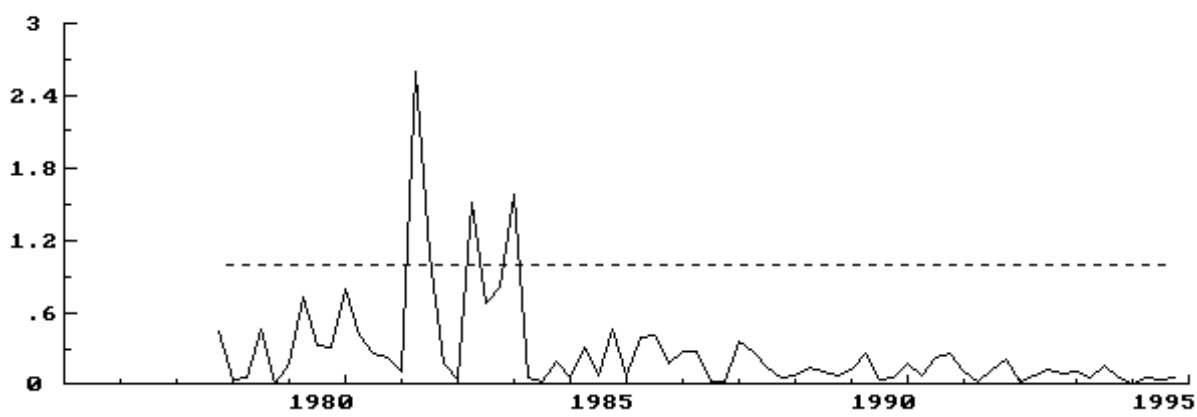

Reading : the former graph reports the result of the Chow test for the stability of the SMIC equation parameters. The latter tests the global stability of the set of parameters of the estimated VAR-ECM. In both cases the structural break is located in the second quarter of 1981.

This structural break implies to distinguish two sub-periods and to estimate a specific VAR-ECM model for each of these sub-periods. The former (1970-1/1981-01) corresponds to the rise of inflation and to the decrease of employee inequalities (measured by the ratio of TSH to SMIC). The latter (1981-02/1999-4) is that of the control of inflation and employee inequality stability.

\section{A cointegrating relationship in each of the two sub-periods}

The lag length choice used in the specification of the unrestricted VAR-ECM model can significantly influenced the estimation results and it is thus crucial to determine it both on economic and statistical considerations (see Gonzalo, 1994). Three criteria have been used here : (i) the Schwarz' bayesian information criterion and the Hannan-Quinn criterion as well as global Fisher's tests, (ii) the absence of autocorrelation and heteroscedasticity in the residuals of the model equations, (iii) the coherence of the estimated parameters with the theoretical expectations. The adopted model consists of a lag of two quarters for the first sub-period and of one quarter for the second sub-period. The two LR test statistics 
(trace test and Lambda max test ${ }^{3}$ ) proposed by Johansen (1988) for cointegration testing and also the critical value taken from Johansen (1995), are reported in table 2. These test statistics indicate the existence of a unique cointegrating relationship between the three variables for each of the two subperiods ${ }^{4}$.

Table 2 - One cointegrating relationship

a) Sub-period 1970-1/1981-01

\begin{tabular}{|c|l|l|l|l|}
\hline \multirow{2}{*}{ Ho against Ha } & \multicolumn{2}{|c|}{$\lambda_{\max }$ Test } & \multicolumn{2}{c|}{$\lambda_{\text {trace }}$ Test } \\
\cline { 2 - 5 } & \multicolumn{1}{|c|}{ Statistic } & $\begin{array}{c}\text { Critical value } \\
\text { (à 5\%) }\end{array}$ & Statistic & $\begin{array}{c}\text { Critical value } \\
\text { (à 5 \%) }\end{array}$ \\
\hline $\mathrm{r}=0$ against $\mathrm{r}=1$ & $27.34 * *$ & 17.9 & $32.87 * *$ & 24.3 \\
\hline $\mathrm{r} \leq 1$ against $\mathrm{r}=2$ & 5.47 & 11.4 & 5.52 & 12.5 \\
\hline $\mathrm{r} \leq 2$ against $\mathrm{r}=3$ & 0.05 & 3.8 & 0.05 & 3.8 \\
\hline
\end{tabular}

** indicate significance at $10 \%$

\footnotetext{
${ }^{3}$ The Lambda max test statistic is the likelihood ratio of the null hypothesis $\mathrm{H}_{2}(r):$ « there exists at most $r$ cointegration relations » against the alternative hypothesis $\mathrm{H}_{2}(r+1):$ " there exists at most $r+1$ cointegration relations», and the Trace test statistic is the likelihood ratio of the null hypothesis $\mathrm{H}_{2}(r)$ against the alternative hypothesis $\mathrm{H}_{1}(n)$ « there exists $n$ cointegration relations », with $r=n, \ldots, 0$.

${ }^{4}$ The outcome of the cointegration analysis remains unchanged if we use the critical values recently tabulated by Pesaran, Shin and Smith (1999].
} 
b) Sub-period 1981-02/1999-4

\begin{tabular}{|c|l|c|l|l|}
\hline \multirow{2}{*}{ Ho against $\mathrm{Ha}$} & \multicolumn{2}{|c|}{$\lambda_{\max }$ Test } & \multicolumn{2}{c|}{$\lambda_{\text {trace }}$ Test } \\
\cline { 2 - 6 } & \multicolumn{1}{|c|}{ Statistic } & \multicolumn{1}{c|}{$\begin{array}{c}\text { Critical value } \\
\text { (at } 5 \%)\end{array}$} & Statistic & \multicolumn{1}{c|}{$\begin{array}{c}\text { Critical value } \\
(\text { at } 5 \%)\end{array}$} \\
\hline $\mathrm{r}=0$ against $\mathrm{r}=1$ & $22.33^{* *}$ & 17.9 & $35.83^{* *}$ & 24.3 \\
\hline $\mathrm{r} \leq 1$ against $\mathrm{r}=2$ & 10.42 & 11.4 & 11.1 & 12.5 \\
\hline $\mathrm{r} \leq 2$ against $\mathrm{r}=3$ & 0.23 & 3.8 & 0.23 & 3.8 \\
\hline
\end{tabular}

** indicate significance at $10 \%$

The estimation of the cointegrating vectors by maximum likelihood are reported below ${ }^{5}$. The coefficient associated to the SMIC is significantly different from zero and has been normalised to 1 , which ensures the identification of the VAR-ECM long-run parameters for the two sub-periods (Johansen, 1995).

1970-1/1981-01

$$
\mathrm{SMIC}=0.8645 \mathrm{ipc}+0.8215 \mathrm{tsh}
$$

1981-02/1999-4

$$
\text { SMIC }=1.287 \mathrm{ipc}+0.3359 \text { tsh }
$$

\section{The full model}

The set of short and long parameters of the two estimated error correction models are reported in table

3.

Table 3 - Estimation of the VAR-ECM parameters

\begin{tabular}{|c|c|c|c|}
\hline Equations & $\Delta$ Lipc & $\Delta$ Lsmic & $\Delta$ Ltsh \\
\hline & $\mathrm{R}^{2}=0.531, \mathrm{DW}=2.048$ & $\mathrm{R}^{2}=0.591, \mathrm{DW}=2.532$ & $\mathrm{R}^{2}=0.707, \mathrm{DW}=1.962$ \\
\hline Variables & Coefficients & Coefficients & Coefficients \\
\hline$\Delta \mathrm{Lipc}_{\mathrm{t}-1}$ & 0.385 & \begin{tabular}{|l|}
1.694 \\
\end{tabular} & 0.612 \\
\hline
\end{tabular}

a) a) Sub-period 1970-1/1981-01

\footnotetext{
${ }^{5} \mathrm{~T}$-stats in parenthesis are for the null hypothesis that the estimated coefficient is equal to zero.

Let us notice that tests on the structure of the cointegrating space have confirmed that the three variables effectively belong to the estimated cointegrating relationship for each of the two sub-periods. Besides, stationarity tests of the different variables implemented in the multivariate framework, where the interdependences between variables are explicitly modelled, are concomitant with those applied previously in the univariate framework. These tests indicate that the variables are characterised by a stochastic non stationarity (namely integrated of order 1), rather than a deterministic non stationarity (namely stationary around a linear deterministic trend). The results of these tests are not reproduced here to save space, but are available on request.
} 


\begin{tabular}{|l||cc||cc||cc|}
$\Delta$ Lipc $_{\mathrm{t}-2}$ & 0.075 & 0.385 & -0.137 & -0.216 & $\mathbf{0 . 6 0 6}$ & 3.922 \\
\hline$\Delta$ Lsmic $_{\mathrm{t}-1}$ & -0.043 & -0.866 & $\mathbf{- 0 . 4 8 9}$ & -3.017 & $\mathbf{- 0 . 0 9 3}$ & -2.376 \\
$\Delta$ Lsmic $_{\mathrm{t}-2}$ & 0.052 & 0.033 & $\mathbf{- 0 . 3 8 1}$ & -2.419 & $\mathbf{- 0 . 0 8 8}$ & -2.299 \\
\hline$\Delta$ Ltsh $_{\mathrm{t}-1}$ & 0.016 & 1.203 & $\mathbf{1 . 2 8 8}$ & 2.018 & 0.003 & 0.023 \\
$\Delta$ Ltsh $_{\mathrm{t}-2}$ & 0.052 & 0.332 & -0.541 & -1.046 & -0.131 & -1.046 \\
\hline ECI $_{\mathrm{t}-1} \mathrm{G}$ & 0.016 & 1.203 & -0.083 & -1.897 & $\mathbf{- 0 . 0 5 1}$ & -4.822 \\
\hline
\end{tabular}

b) b) Sub-period 1981-02/1999-4

\begin{tabular}{|c|c|c|c|c|c|c|}
\hline Equations & & ipc & & mic & & tsh \\
\hline & $\mathrm{R}^{2}=0.792, \mathrm{I}$ & $=2.101$ & $\mathrm{R}^{2}=0.355, \mathrm{D}$ & 1.827 & $\mathrm{R}^{2}=0.798, \mathrm{I}$ & $=2.019$ \\
\hline Variables & \begin{tabular}{|l|} 
Coefficients \\
\end{tabular} & T-Stat & \begin{tabular}{|l|} 
Coefficients \\
\end{tabular} & T-Stat & \begin{tabular}{|l|} 
Coefficients \\
\end{tabular} & T-Stat \\
\hline$\Delta$ Lipc $_{t-1}$ & \begin{tabular}{|l|}
0.361 \\
\end{tabular} & 3.108 & \begin{tabular}{|l|}
1.057 \\
\end{tabular} & 2.748 & \begin{tabular}{|l|}
0.763 \\
\end{tabular} & 5.815 \\
\hline$\Delta$ Lsmic $_{\mathrm{t}-1}$ & \begin{tabular}{|l|}
0.013 \\
\end{tabular} & 0.351 & -0.233 & -1.850 & \begin{tabular}{|l|}
0.019 \\
\end{tabular} & 0.443 \\
\hline$\Delta \mathrm{Ltsh}_{\mathrm{t}-1}$ & -0.051 & 0.581 & -0.062 & -0.214 & -0.042 & 0.421 \\
\hline $\mathrm{ECI}_{\mathrm{t}-1}{ }^{7}$ & \begin{tabular}{|l|}
-0.075 \\
\end{tabular} & -4.995 & -0.041 & -0.823 & \begin{tabular}{|l|}
-0.034 \\
\end{tabular} & -2.000 \\
\hline
\end{tabular}

The coefficients in bold are statistically significant at the $5 \%$ level.

Moreover several test statistics have been calculated in order to check the quality of the multivariate estimation (Lagrange Multiplicator test (LM) and Ljung-Box test for serial correlation of order 16, ARCH tests (Autoregressive Conditional Heteroscedasticity), Jarque-Bera normality test). The tests constitute a good way to detect the possible failing of some hypotheses made during the system estimation. In order not to make the presentation cumbersome, the results of these tests are not reported here, but they indicate that the two VAR-ECM models are well behaved and not subject to misspecification, since the usual hypotheses concerning the residuals of each of the three equations are verified $^{8}$. Finally, the re-estimation of the two models by recursive least squares with the Pc-Give software and the implementation of Chow tests confirms the stability of the parameters of the two models for each of the sub-periods.

\section{Dynamic interaction between the SMIC, inflation and wages}

\footnotetext{
${ }^{6}$ It must be underlined that the stationary term $\mathrm{ECI}_{\mathrm{t}-1}$ is defined as $\mathrm{ECI}_{\mathrm{t}-1}=0.8645 \mathrm{ipc}_{\mathrm{t}-1}+0.8215 \mathrm{tsh}_{\mathrm{t}-1}-\mathrm{smic}_{\mathrm{t}-1}$.

${ }^{7}$ Likewise in the second error correction model the stationary term $\mathrm{ECI}_{\mathrm{t}-1}$ is defined as : $\mathrm{ECI}_{\mathrm{t}-1}=1.287 \mathrm{ipc}_{\mathrm{t}-1}+0.3359 \mathrm{tsh}_{\mathrm{t}-1}-\mathrm{smic}_{\mathrm{t}-1}$.

${ }^{8}$ The residuals of the conditional VAR-ECM model equations have on the whole good properties : they don't suffer from serial correlation, are not of ARCH type, even if they sometimes have normality problems. This lack of normality assumption in some equations is actually not very serious for the conclusions of the study, since as noted by Johansen (1995), the asymptotic properties of the Maximum Likelihood method only depend on the i.i.d assumption of the errors.
} 
The two VAR-ECM models being well specified and their parameters steady through time, one can make use of them to investigate the dynamic relationships between the three variables using three tools generally employed by economists, namely causality tests, the variance decompositions (VDCs) of forecast error and impulse response functions (IRFs) to shocks (cf. appendix 1).

\section{Which causalities?}

The results of the causality tests in Granger's sense (1969) are reported in Table 4. In the short run causality means that wage growth rate for instance has a delayed impact on the SMIC growth rate. In the case of a long-run causality it is the equilibrium between wage level and that of other variables which determines the SMIC increase.

Table 4 - Causality test results

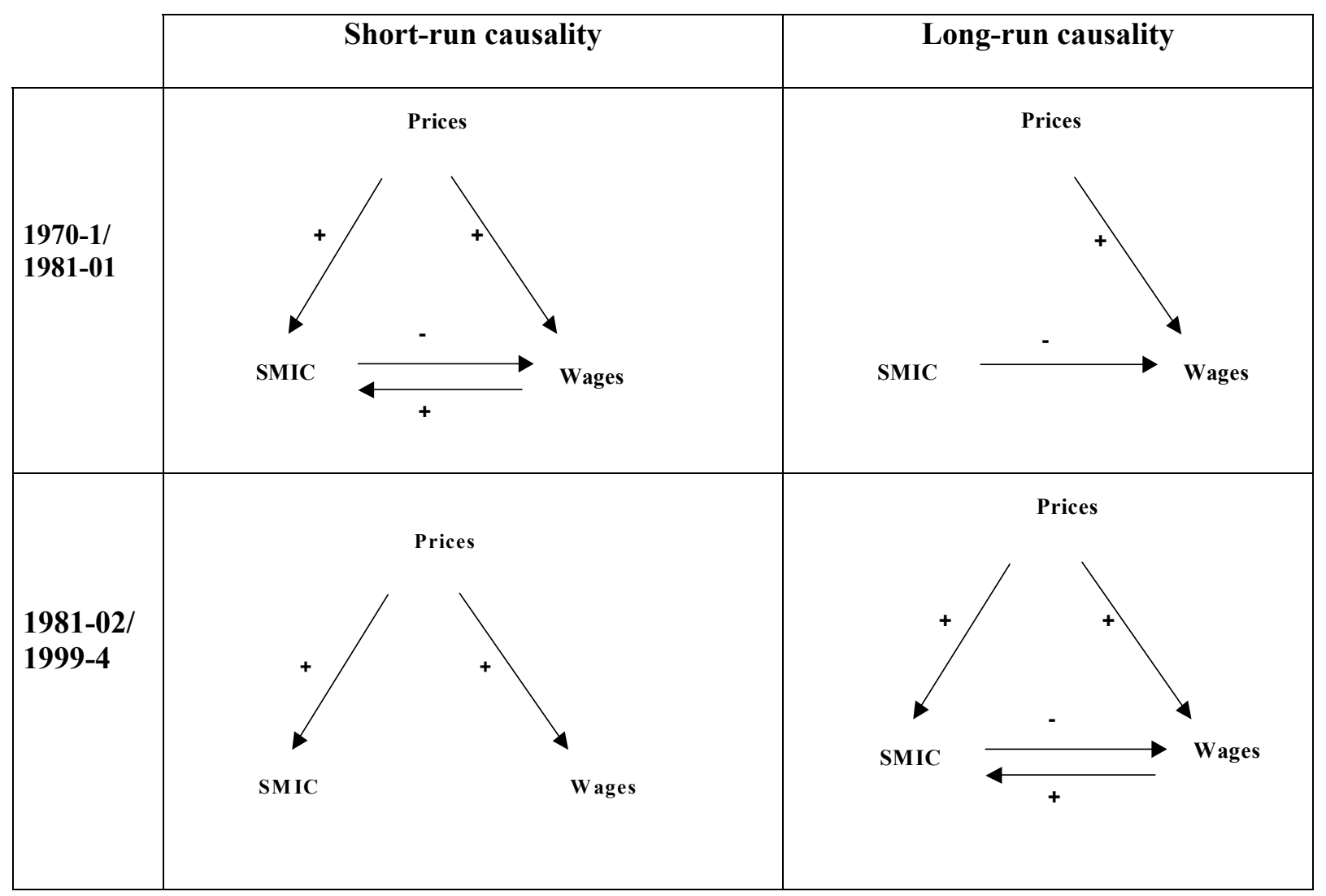


None of these causalities is conflicting with the theoretical and institutional expectations. But some differences are however notable between the two sub-periods. Before 1981 short-run causalities which link variable growth of rates are more present than long-run causalities which are associated with the variable level. It is the contrary after 1981. In other words, dynamic relationships are predominant in the former sub-period, and equilibrium relationships in the latter.

If one focuses on the short-run, it first appears that inflation causes the SMIC increase in the two subperiods, but it is not itself caused by any of the other variables. SMIC increases are determined by those of wages only before 1981. They have then moderating feedback effects on wage rise. Theoretically this moderating mechanism is connected to a volume effect higher than substitution effects (we consider here the short-run). Since 1981, there have not been more causal relationships between the SMIC increase and that of wages

In the long-run wage rises are sensitive in the two sub-periods to the equilibrium between wages, the SMIC and price level, which constitute the target of an error correcting term mechanism (the SMIC having again a moderating effect on wage increase, which has however been weakly significant since 1981). SMIC rises don't depend on any equilibrium relationships between these three variables in the two sub-periods. Finally, inflation has been sensitive to the target of the error correcting term mechanism between variables in level only since 1981 .

The forecast error variance decomposition exercise permits to order the variable from the most to the least exogenous one (see Appendix 1). It appears that inflation is the most exogenous variable and that the SMIC is the most endogenous one as it was suggested by the minimum wage institutional mode of formation The ordering $\mathrm{X}_{\mathrm{t}}=\left(\mathrm{ipc}_{\mathrm{t}}, \mathrm{tsh}_{\mathrm{t}} \mathrm{SMIC}_{\mathrm{t}}\right)$ is then used to calculate the impulse response functions (IRFs) to shocks affecting the three variables. Note that with the variance-covariance matrix of the errors of the two estimated VAR-ECM models being here near diagonal, the results of the impulse 
analysis are actually not sensitive to the predetermined variable ordering (contrary to the general case) and consequently the results presented above are robust.

\section{Long-run effects of price increase}

Tables reported below correspond to the long-run response of the three variables following a shock of $1 \%$ on one of these variables, given the set on interdependences existing between the three variables. Generally speaking, the two estimated error correction models have a quick capacity to absorb shocks : in fact, they are completely absorbed in about 12 quarters (great maximum) in the first sub-period, and in about 5 quarters in the second sub-period (where adjustments are faster).

These long-run responses give directly the nominal effects of shocks. The difference between the response of wages or SMIC and that of prices give the real impact of shocks. The difference between the response of wages and that of SMIC indicates eventually the impact on wage inequalities. Firstly concerning the impact of a price increase we can make three observations.

- Following an exogenous consumer price increase of 1 point, the connections seem globally much more inflationist in the former sub-period than in the latter. Prices have finally risen of 3 points before 1981, and only of 1.5 point since 1981 (see table 5). The nominal impact on wages and on the SMIC is also much higher before 1981.

- In the two sub-periods, wages appear to be slightly under-indexed to inflation: a price increase leads finally to a slight decrease of wage purchasing power. As for the SMIC, it seems to be over-indexed in the two sub-periods: the minimum wage purchasing power increases by approximately one third more than the accumulated price rise.

- Inflation also reduces wage inequalities by bringing closer the SMIC purchasing power to that of hourly wage rate. The institutional mechanisms of SMIC indexation to consumer prices 
make that SMIC employees are always more protected against price rise effects than other employees. Through this channel desinflation may have contributed to a least employee inequality reduction.

Table 5 - Long-run responses following a shock on consumer price index ${ }^{9}$

\begin{tabular}{|l|c|c|}
\hline & Before 1981 & After 1981 \\
\hline Prices & 3,06 & 1,5 \\
\hline SMIC & 4,19 & 1,96 \\
\hline Wages & 2,86 & 1,37 \\
\hline
\end{tabular}

\section{Long-run effects of wage increase}

The same problematic can be adopted here to examine and comment on the long-run effects of an exogenous hourly wage rate rise.

- Again nominal effects appear to be much higher before 1981. Prices have finally risen of half a point in the first sub-period whereas they have remained stable in the second one, or have slightly decreased. A theoretical interpretation is that of a competition intensification on the goods markets between the two periods, wage rises being less transferred on prices in more open markets. Wage and SMIC nominal increases are also higher in the first sub-period. Since 1981 an exogenous wage increase of one point has only led to a final rise of 0.9 point and to a weak minimum wage moderation of approximately 0.1 point and equally for prices.

- The real effects are however somewhat higher in the second sub-period. Having no more inflationist effects wage rises are finally more profitable for employee purchasing power (the

\footnotetext{
${ }^{9}$ The $5 \%$ confidence interval of each of the response functions has been calculated using the bootstrap method by carrying out 1000 simulations and is given in Appendix 1.
} 
difference is however very small: the purchasing power gain is of 0.77 point before 1981 and of 0.83 after). They are less profitable for SMIC employees whose purchasing power has been insensitive to wage increases since 1981 whereas they had increased of 0.4 point before.

- Since wage increases are less profitable for SMIC employees, they have finally a much more non-egalitarian effect in the period of disinflation. They have made the SMIC move apart from hourly wage rate by .0 .3 point before 1981 , against 1 point since then.

Table 6 -Long-run responses following a shock on hourly wage rate ${ }^{10}$

\begin{tabular}{|l|c|c|}
\hline & Before 1981 & After 1981 \\
\hline Prices & 0,49 & $-0,07$ \\
\hline SMIC & 0,91 & $-0,11$ \\
\hline Wages & 1,26 & 0,9 \\
\hline
\end{tabular}

\section{Long-run effects of SMIC increase}

A last simulation enables us to investigate the impact of a SMIC rise on prices and other wages. The result is reported in table 7 .

Table 7 - Long-run responses following a shock on the SMIC ${ }^{11}$

\begin{tabular}{|l|c|c|}
\hline & Before 1981 & After 1981 \\
\hline Prices & 0,02 & 0,019 \\
\hline SMIC & 0,54 & 0,83 \\
\hline Wages & $-0,02$ & $-0,015$ \\
\hline
\end{tabular}

- Nominal effects are very low in the two sub-periods. The SMIC rise has partly a persistent effect, a little more after 1981 than before. Inflation and wages hardly vary. As a consequence

\footnotetext{
${ }^{10}$ The $5 \%$ confidence interval of each of the response functions has been calculated using the bootstrap method by carrying out 1000 simulations and is given in Appendix 1 .

${ }^{11}$ The $5 \%$ confidence interval of each of the response functions has been calculated using the bootstrap method by carrying out 1000 simulations and is given in Appendix 1.
} 
when the interdependences between variables are taken into account minimum wage rises would have then a quite insignificant effect on other wages.

- In the absence of any persistent impact on prices, real effects correspond to nominal effects. SMIC increases have a little more favourable impact on SMIC employee purchasing power paid in a context of controlled inflation

- Concerning social inequalities the effect of the squeezing of the wage range related to SMIC increases has always been less important ex post than ex ante, but the ex post effect has been higher since 1981. The SMIC would have gained in efficiency as an instrument of wage disparity reduction.

\section{Conclusion}

The period of inflation rise from 1970 to 1981 coincided with an important squeeze of the wage range, measured by the difference of the minimum wage to the hourly wage rate (TSH). The period of disinflation since 1981, as far as it is concerned, has been concomitant with a stability of wage inequalities. The results of this study suggest a relationship between the evolutions of inflation and wage disparities and enable us to draw up a mixed assessment of the disinflation effects on wage formation and the SMIC.

On the one side, disinflation has hardly benefited the SMIC evolution. Before 1981 the SMIC had always profited by price and wage rises, given the interdependences between those variables. Since 1981, it has always benefited from price rises, both in real and relative terms, but they have become less strong, and it doesn't benefit wage rises anymore. On the other, the SMIC seems however to have gained in efficiency as an instrument of wage disparity reduction. Its rises are finally more persistent in real terms and relatively to the other salaries and they have always had as little inflationary impact on wages as on prices. 


\section{Appendix 1 : Impulse analysis}

The two exercises of variance decompositions (VDCs) of forecast error and impulse response functions (IRFs) to shocks are implemented here in so far as Granger causality tests applied previously rest principally upon a notion of anteriority between variables and can besides be viewed as within sample causality tests. Indeed, these tests can only reveal causality within the sample period, but don't provide us with an indication of the dynamic properties of the variable system, nor do they allow us to gauge the relative strength and exogenity degree of the different variables beyond the sample period. On the other hand, VDC that may be termed as out-of sample causality tests, by partitioning the variance of the forecast error of a certain variable (for instance the SMIC) for different horizons of forecast into proportions attributable to innovations (or shocks) in each variable in the system, including its own, can provide an indication of these relativities.

To carry out our impulse analysis, we perform in a first step a Cholesky decomposition of error variancecovariance matrix, so as to get an orthogonalised VAR representation with contemporaneously uncorrelated errors. Note that this kind or orthogonalisation initiated by Sims (1972) is in general not neutral, in the extent that it imposes an identification schema of recursive type. One has then to order the variables from the most to the least important one, that is from the most to the least exogenous. To determine the more adequate ordering we use both the statistical tool and economic theory and it is important to note that these two instruments provide a unified answer. The analysis of causality test results leads us to put as contemporaneous variable in each VARECM model the one whose causality measure is the most important (that is, the variable that causes the most the others, and which is the least caused by the latter). We carry on in the same way to order the other variables, which leads us in fine to retain an $X_{t}$ vector whose variables are ordered as follow (ipc, tsh SMIC). It is important to notice that the variance-covariance matrix being here near diagonal a different variable ordering of the VAR-ECM model will actually modify only very marginally the Cholesky factor (contrary to the general case). An important implication of this is that our results presented above are robust to a different variables ordering.

The variance decompositions (VDCs) of forecast error and the impulse response functions (IRFs) to shocks (the shock is of $1 \%$ ) are then calculated for the variables taken in level for a sufficiently long temporal horizon for all responses to stabilise and to come back towards zero, which indicates that the two VAR-ECM models are correctly specified and that all the variables are integrated of order zero (I (0)). We then deduce by summation the IRF for each variable taken in level as well as the decomposition of forecast error variance at different horizons for each variables taken in level.

We also calculate the $5 \%$ confidence interval of each response functions using the bootstrap method, which enables to do without the two fundamental hypotheses which are often required by classical tests, namely residual normality and large samples. In effect, these two hypotheses are not always satisfied as it is for instance the case here : our two samples only concern 12 and 19 years (which is a borderline size) and residual normality is sometimes rejected. Bootstrap is a non parametric method whose basic idea is that residual empirical distribution converges towards residual true distribution. Thus by simulating the system with those residuals and by re-estimating the model a great number of times, one can derive the finite distance distribution of the model parameters (see Bertail, 1992 for a survey. The impulse response functions to shocks and the results of the variance decompositions of forecast error exercise are reported and commented below and permit to stress the main channels of influence in the two VAR-ECM model.

\section{Impulse Response functions (IRFs)}

The impulse response functions (IRFs) to shocks of the three variables following a shock of $1 \%$ on one of these variables are reported below for each sub-period. We consider successively a shock on the consumer price index (ipc), on the workers 'hourly wage rate (tsh) and on the SMIC nominal level (smic). 
TABLEAU 1 - Variable responses to a $1 \%$ shock on the consumer price index (ipc)

1970:01-1981:01
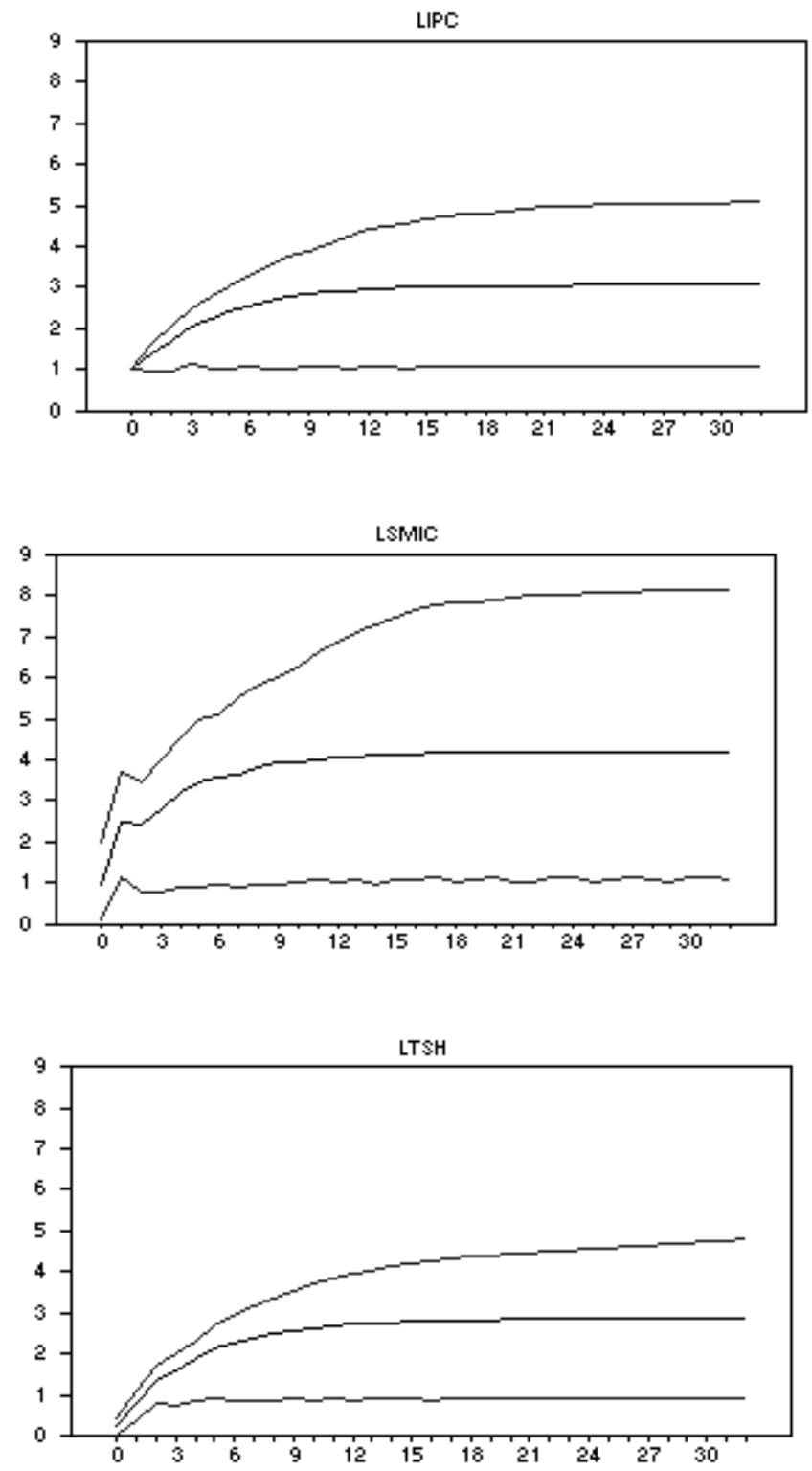

1981:02- 1999:04
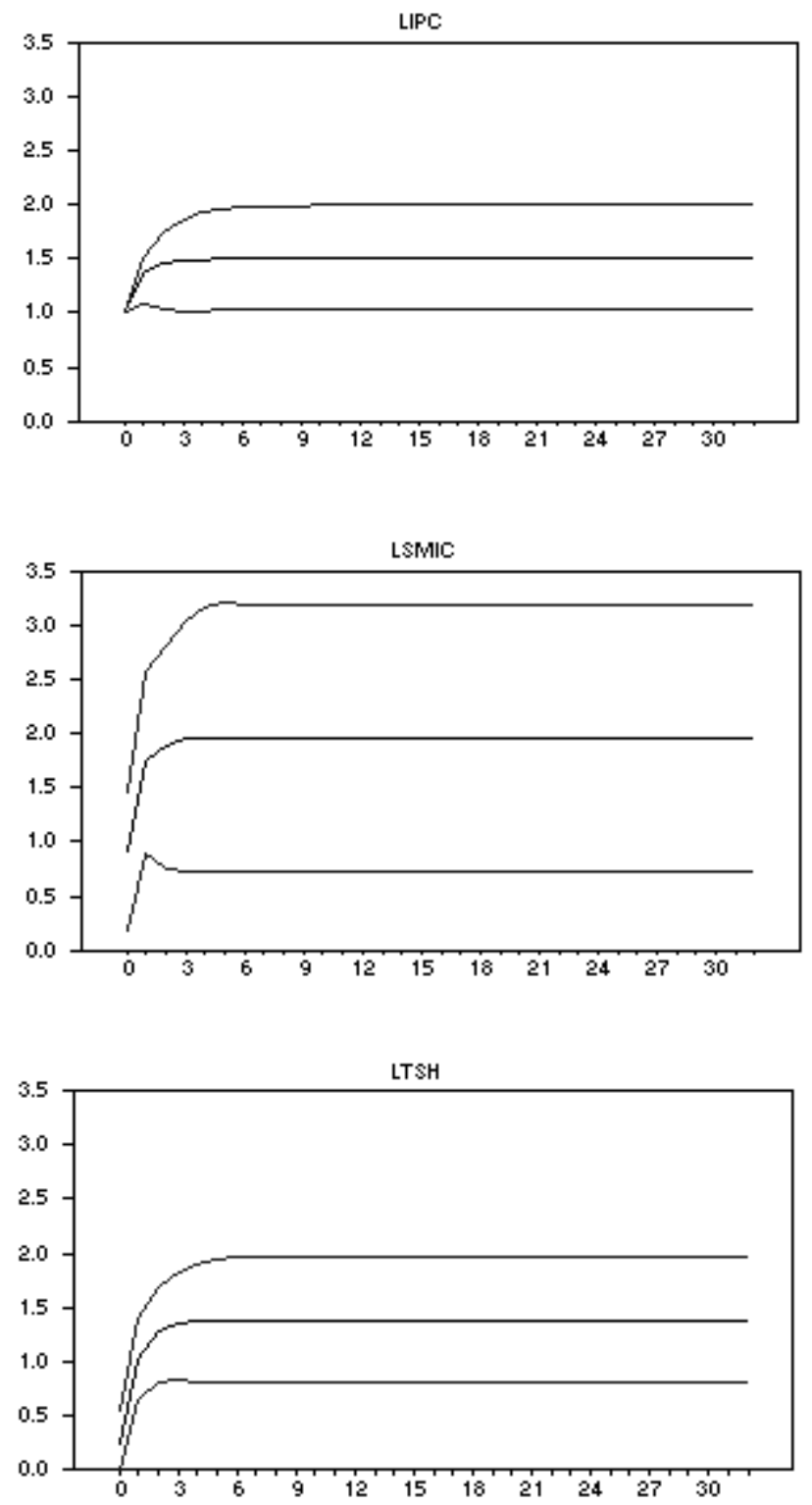

Nota :

The $5 \%$ confidence interval of each of the response functions has been calculated using the bootstrap method (cf. infra ) by carrying out 1000 simulations. 
TABLEAU 2 - Variable responses to a $1 \%$ shock on the workers 'hourly wage rate (tsh)

1970:01-1981:01
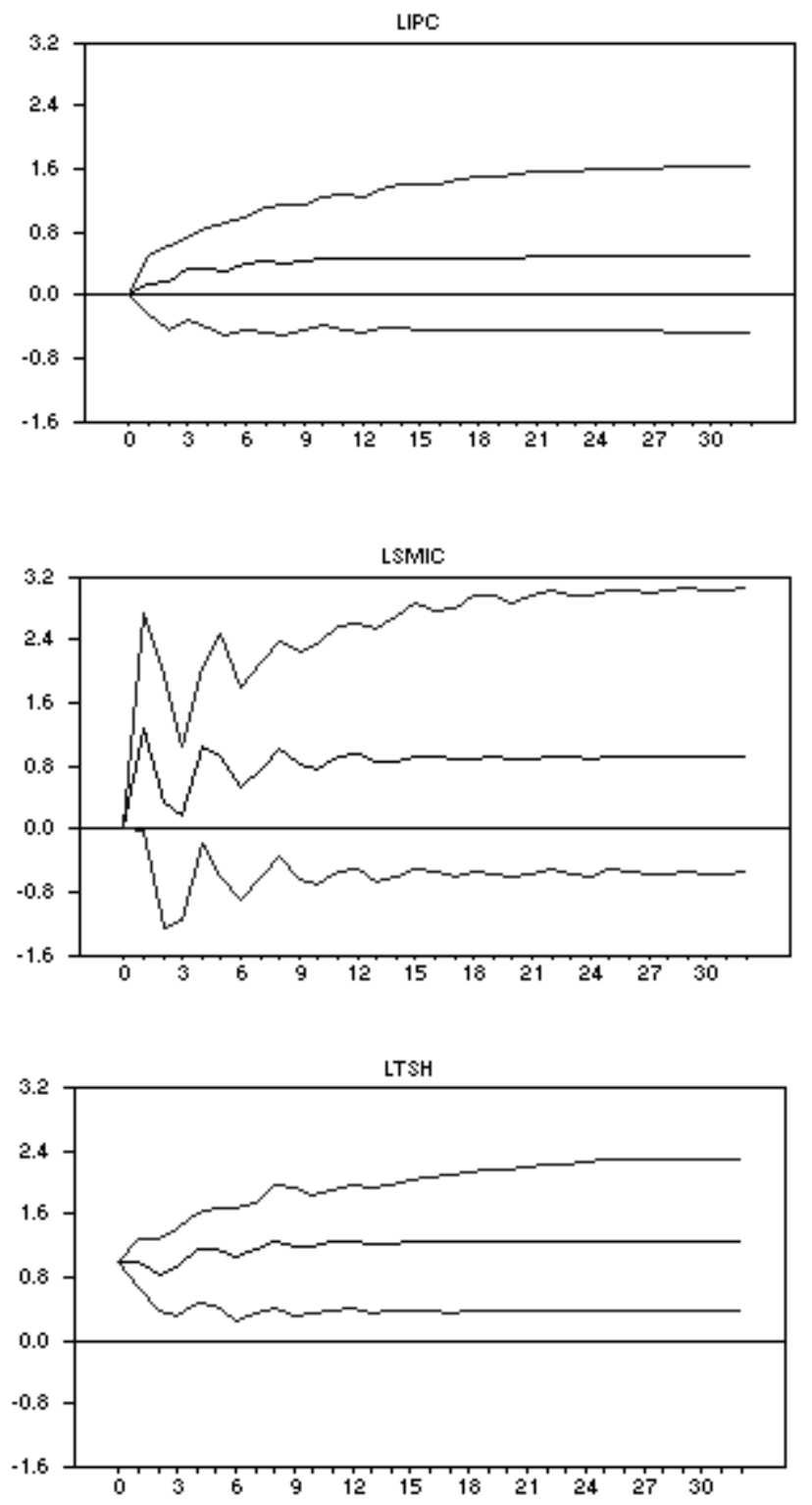

1981:02- 1999:04
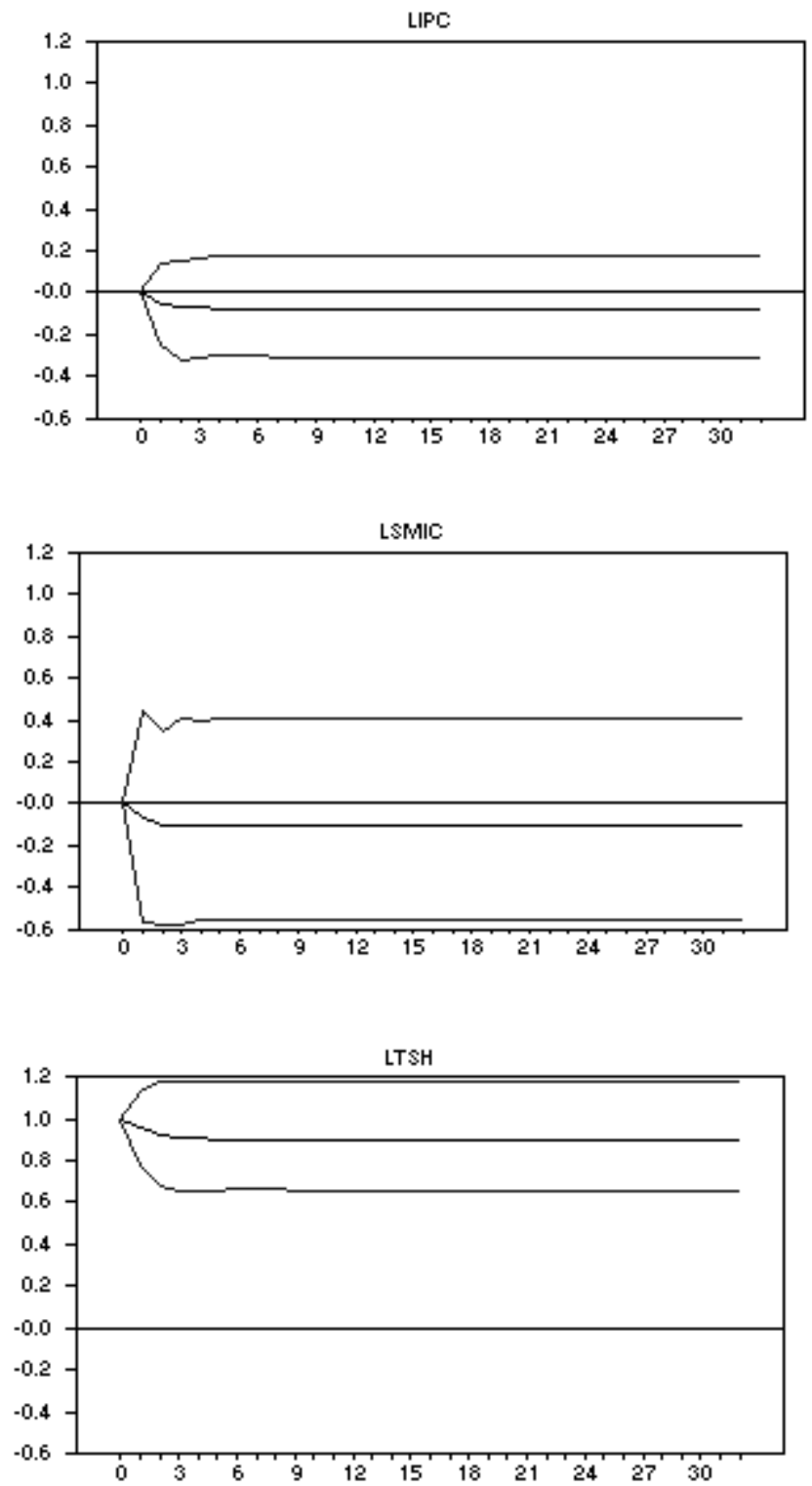

\section{Nota :}

The $5 \%$ confidence interval of each of the response functions has been calculated using the bootstrap method (cf. infra ) by carrying out 1000 simulations. 


\section{TABLEAU 3 - Variable responses to a 1\% shock on the SMIC nominal level (smic).}

1970:01-1981:01
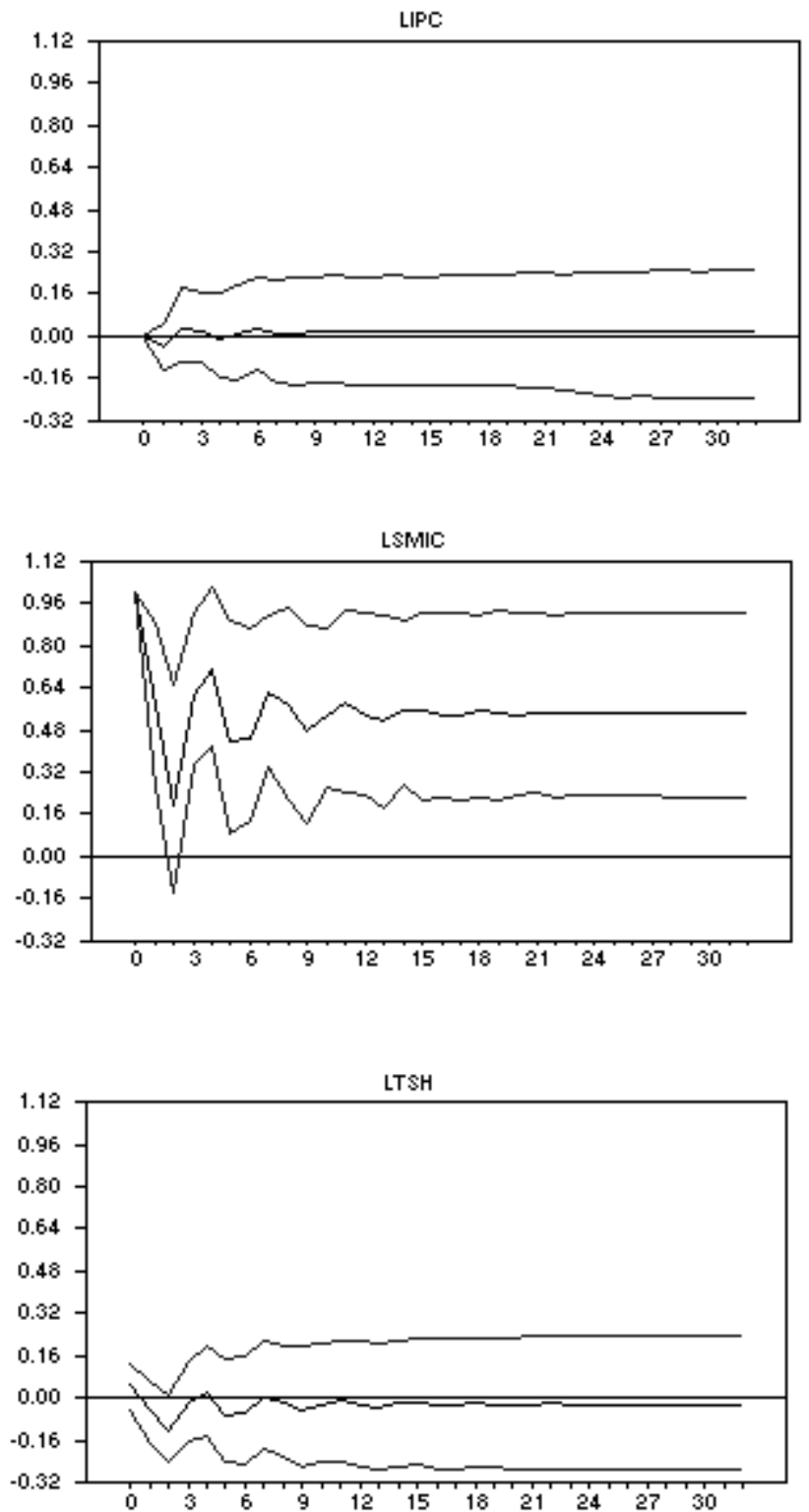

1981:02- 1999:04
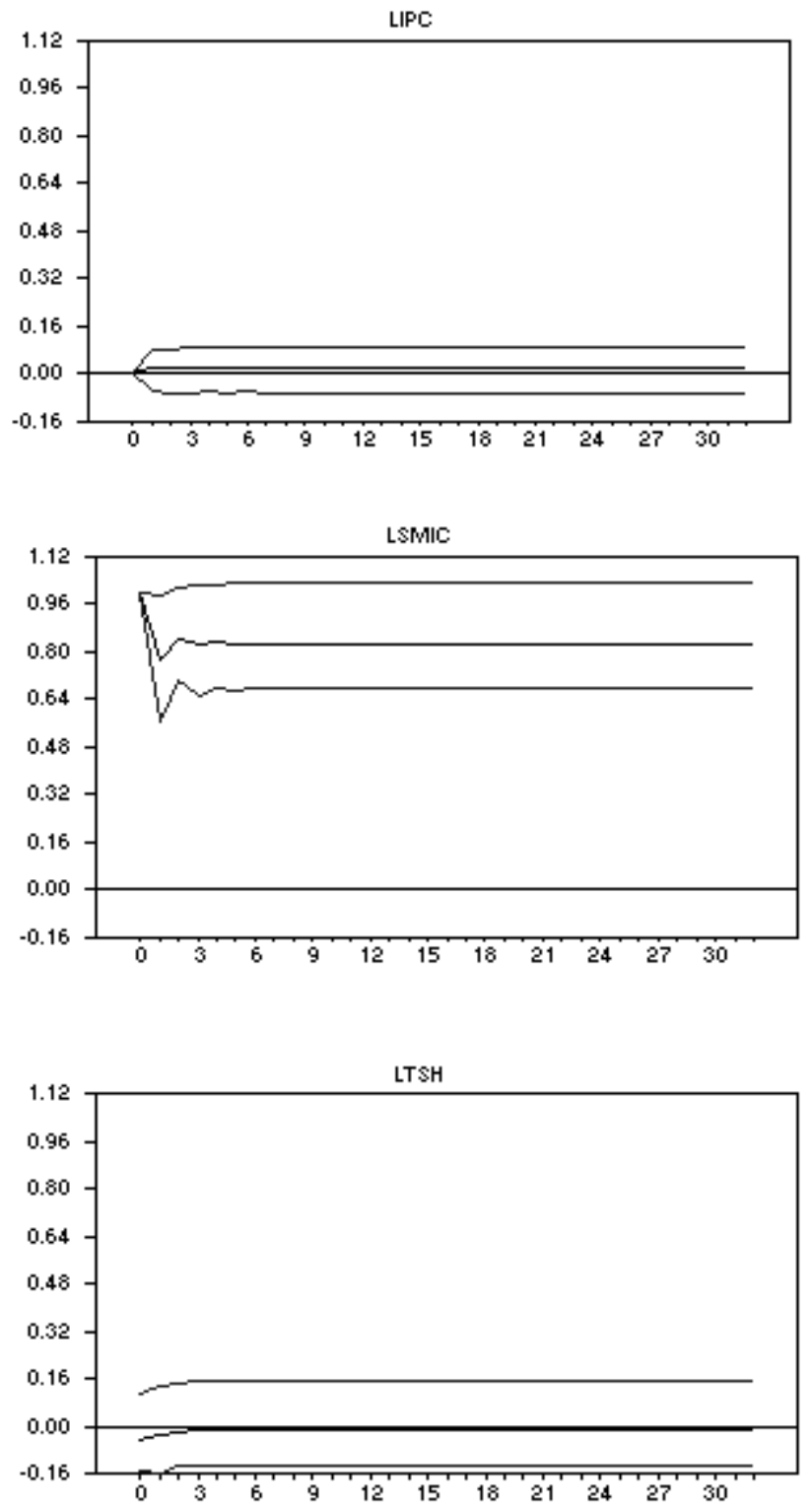

Nota :

The $5 \%$ confidence interval of each of the response functions has been calculated using the bootstrap method (cf. infra ) by carrying out 1000 simulations. 
Decomposition of forecast error variance at different horizons for the variables (ipc, tsh, smic) taken in level

a) Sub-period 1970-01/1981-01

\begin{tabular}{|c|c|c|c|c|}
\hline \multicolumn{2}{|c|}{$\begin{array}{l}\mathrm{h}=\text { horizon of forecast } \\
\text { (in quarters) }\end{array}$} & \multicolumn{3}{|c|}{ Percentage of forecast error variance } \\
\hline & & ipc & tsh & SMIC \\
\hline ipc & $\begin{array}{l}1 \\
2 \\
5 \\
10 \\
20 \\
32\end{array}$ & $\begin{array}{c}100 \\
99.03 \\
98.17 \\
97.71 \\
97.50 \\
97.43\end{array}$ & $\begin{array}{l}0.00 \\
0.73 \\
1.80 \\
1.99 \\
1.47 \\
1.54\end{array}$ & $\begin{array}{l}0.00 \\
0.04 \\
0.03 \\
0.03 \\
0.03 \\
0.03\end{array}$ \\
\hline tsh & $\begin{array}{l}1 \\
2 \\
5 \\
10 \\
20 \\
32\end{array}$ & $\begin{array}{c}0.00 \\
42.29 \\
62.39 \\
73.14 \\
77.69 \\
79.12\end{array}$ & $\begin{array}{c}100 \\
56.98 \\
36.86 \\
26.11 \\
21.56 \\
21.15\end{array}$ & $\begin{array}{l}0.00 \\
0.73 \\
0.75 \\
0.75 \\
0.75 \\
0.73\end{array}$ \\
\hline smic & $\begin{array}{l}1 \\
2 \\
5 \\
10 \\
20 \\
32\end{array}$ & $\begin{array}{c}0.00 \\
71.11 \\
81.05 \\
87.80 \\
90.12 \\
90.88\end{array}$ & $\begin{array}{c}0.00 \\
16.77 \\
11.83 \\
8.12 \\
7.47 \\
6.71\end{array}$ & $\begin{array}{c}100 \\
12.12 \\
7.07 \\
4.08 \\
2.41 \\
2.41\end{array}$ \\
\hline
\end{tabular}

b) Sub-period 1981-02/1999-4

\begin{tabular}{|c|c|c|c|c|}
\hline \multicolumn{2}{|c|}{$\begin{array}{l}\mathrm{h}=\text { horizon of forecast } \\
\text { (in quarters) }\end{array}$} & \multicolumn{3}{|c|}{ Percentage of forecast error variance } \\
\hline & & ipc & tsh & SMIC \\
\hline ipc & $\begin{array}{l}1 \\
2 \\
5 \\
10 \\
20 \\
32\end{array}$ & $\begin{array}{c}100 \\
99.84 \\
99.78 \\
99.76 \\
99.75 \\
99.75\end{array}$ & $\begin{array}{l}0.00 \\
0.15 \\
0.21 \\
0.23 \\
0.24 \\
0.24\end{array}$ & $\begin{array}{l}0.00 \\
0.01 \\
0.01 \\
0.01 \\
0.01 \\
0.01\end{array}$ \\
\hline tsh & $\begin{array}{l}1 \\
2 \\
5 \\
10 \\
20 \\
32 \\
\end{array}$ & $\begin{array}{c}0.00 \\
37.20 \\
50.58 \\
55.55 \\
58.12 \\
59.08\end{array}$ & $\begin{array}{c}100 \\
62.80 \\
49.42 \\
44.45 \\
41.88 \\
41.92\end{array}$ & $\begin{array}{l}0.00 \\
0.00 \\
0.00 \\
0.00 \\
0.00 \\
0.00\end{array}$ \\
\hline smic & $\begin{array}{l}1 \\
2 \\
5 \\
10 \\
20 \\
32\end{array}$ & $\begin{array}{c}0.00 \\
51.37 \\
61.37 \\
64.99 \\
66.83 \\
67.53\end{array}$ & $\begin{array}{l}0.00 \\
0.30 \\
0.44 \\
0.50 \\
0.53 \\
0.54\end{array}$ & $\begin{array}{c}100 \\
48.33 \\
38.19 \\
34.51 \\
32.64 \\
31.93\end{array}$ \\
\hline
\end{tabular}

Nota :

It must be underlined that a strictly exogenous variable should have in the table above, if there were no estimation errors in the system parameters some " 100 " in its diagonal cells and some " 0 " in any other column cells. In effect, according to Sims (1972), the exogeneity of a variable is equivalent to the condition that this variable "innovation" accounts for all its forecast error variance at all horizons.

Generally speaking, as far as the variance decomposition of forecast error is concerned, the first three rows of the table above indicate that one relationship appears strikingly. Indeed, :the variance forecast error of the three variables is accounted for by the consumer price index innovation for each of the two sub-periods and at all temporal horizons (respectively $99.75 \%$ for ipc, $59.08 \%$ for tsh and $67.53 \%$ for SMIC smic at 8 year horizon for the period 1981:02-1999:04). Thus, the shock on ipc constitutes the predominating shock. Furthermore, if the definition of Sims (1980) is used to evaluate the variable exogeneity degree of the two VAR-ECM models one reaches the following variable ordering from the most to the least exogenous (ipc, tsh, smic). The SMIC thus appears as the most endogenous variable. Let us recall that with the variance-covariance matrix being here near diagonal, the results of the impulse analysis are not sensitive to the predetermined variable ordering (contrary to the general case). 
Appendix 2

Graphs of the series (in level and in first differences)
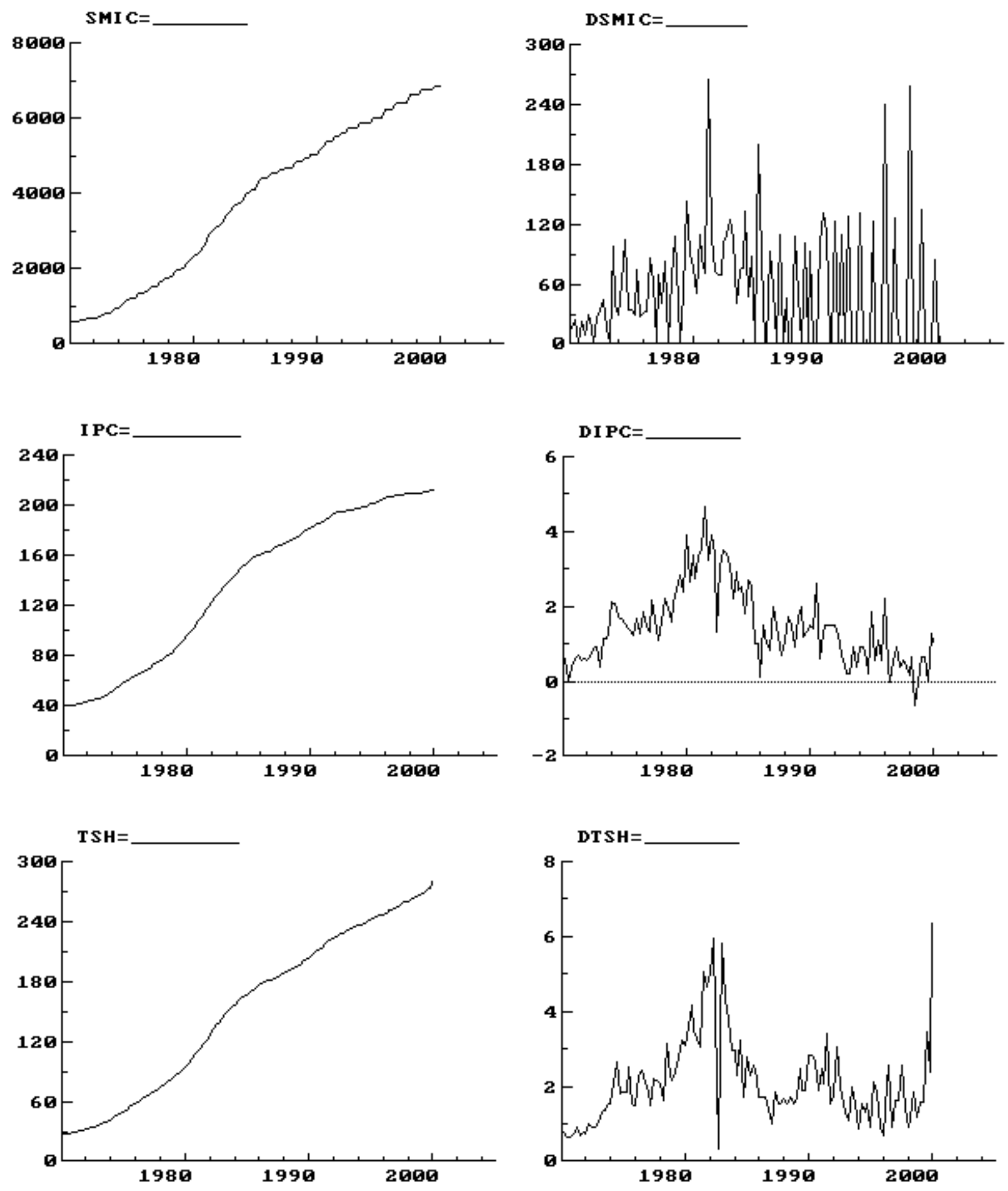

25 


\section{REFERENCES}

Bertrail P.(1992), "Le bootstrap, une revue de littérature", Insee, Document de travail,

Chauvin V. Heyer E. (2001) “L’affaire des sept SMIC”, Lettre de l’OFCE, n²07.

CSERC (1999), "Le salaire minimum de croissance". La documentation française,

Dolado J., Kramarz F., Machin S., Manning A., Margolis D. et Teulings C. (1996), "The economic impact of minimum wages in Europe", Economic Policy, $\mathrm{n}^{\circ} 23$.

Elliott G., Rothenberg T.H, Stock J.H (1996), "Efficient tests for an autoregressive unit root", Econometrica, vol 64, pp 813-836.

Granger C. (1969), "Investigating Causal Relations Econometrics Models and Cross Spectral Methods", Econometrica, vol. 37, pp. 424-439, juillet.

Grossman J-B. (1983), "The Impact of the Minimum Wage on other Wages", The Journal of Human Ressources, XVIII, 3.

Im K., Pesaran H., Shin Y. (1997), "Testing for unit roots in heterogeneous panels", Discussion Paper, University of Cambridge, June.

Jobert I. (1992), “Test de racine unitaire”, Cahiers Eco\&Maths, Université de Paris I, n92,44.

Johansen S. (1988), "Statistical analysis of cointegration vectors", Journal of Economic Dynamics and Control, vol 12, pp 231-254.

Johansen, S. (1995), "Likelihood-Based Inferences in Cointegration Vector Autoregressive Models", Advanced Texts in Econometrics, 267p. Oxford and New York : Oxford University Press.

Kwiatowski D., Phillips P.C.B., Schmidt P. \& Shin Y.(1992), "Testing the Null Hypothesis of Stationarity Against the Alternative of a Unit Root: How Sure Are We That Economic Time Series Have a Unit Root? ", Journal of Econometrics, Vol. 54: 159-178.

OCDE (1998), "Tirer le meilleur parti du salaire minimum: salaire minimum légal, emploi et pauvreté". Perspectives de l'Emploi, juillet.

Sims C. (1972), “Money, Income and Causality”, American Economic Review », vol. 62, pp. 540-552.

Sims C. (1980), "Macroeconomics and Reality", Econometrica, 48, 1-48.

Stigler G.J. (1946). "The economics of minimum wage legislation", American Economic Review, vol 36. 


\section{IZA Discussion Papers}

\begin{tabular}{|c|c|c|c|c|}
\hline No. & Author(s) & Title & Area & Date \\
\hline 847 & B. R. Chiswick & $\begin{array}{l}\text { Jacob Mincer, Experience and the Distribution of } \\
\text { Earnings }\end{array}$ & 1 & 08/03 \\
\hline 848 & $\begin{array}{l}\text { A. Chevalier } \\
\text { G. Conlon }\end{array}$ & Does It Pay to Attend a Prestigious University? & 6 & $08 / 03$ \\
\hline 849 & W. Schnedler & Traits, Imitation, and Evolutionary Dynamics & 5 & $08 / 03$ \\
\hline 850 & $\begin{array}{l}\text { S. P. Jenkins } \\
\text { L. Osberg }\end{array}$ & $\begin{array}{l}\text { Nobody to Play with? The Implications of } \\
\text { Leisure Coordination }\end{array}$ & 5 & 08/03 \\
\hline 851 & J. D. Angrist & $\begin{array}{l}\text { Treatment Effect Heterogeneity in Theory and } \\
\text { Practice }\end{array}$ & 6 & $08 / 03$ \\
\hline 852 & $\begin{array}{l}\text { A. Kugler } \\
\text { M. Kugler }\end{array}$ & $\begin{array}{l}\text { The Labor Market Effects of Payroll Taxes in a } \\
\text { Middle-Income Country: Evidence from } \\
\text { Colombia }\end{array}$ & 1 & $08 / 03$ \\
\hline 853 & $\begin{array}{l}\text { I. Ekeland } \\
\text { J. J. Heckman } \\
\text { L. Nesheim }\end{array}$ & Identification and Estimation of Hedonic Models & 6 & 08/03 \\
\hline 854 & $\begin{array}{l}\text { A. Ferrer-i-Carbonell } \\
\text { B. M. S. Van Praag }\end{array}$ & Income Satisfaction Inequality and Its Causes & 3 & $08 / 03$ \\
\hline 855 & $\begin{array}{l}\text { B. Irlenbusch } \\
\text { D. Sliwka }\end{array}$ & $\begin{array}{l}\text { Career Concerns in a Simple Experimental } \\
\text { Labour Market }\end{array}$ & 1 & $08 / 03$ \\
\hline 856 & D. Sliwka & $\begin{array}{l}\text { Management Incentives, Signaling Effects and } \\
\text { the Costs of Vertical Integration }\end{array}$ & 1 & $08 / 03$ \\
\hline 857 & $\begin{array}{l}\text { M. Francesconi } \\
\text { A. Muthoo }\end{array}$ & An Economic Model of Child Custody & 3 & $08 / 03$ \\
\hline 858 & C. U. Chiswick & $\begin{array}{l}\text { History of Historical Statistics of the United } \\
\text { States }\end{array}$ & 7 & $08 / 03$ \\
\hline 859 & R. Fahr & $\begin{array}{l}\text { Loafing or Learning? The Demand for Informal } \\
\text { Education }\end{array}$ & 5 & $08 / 03$ \\
\hline 860 & $\begin{array}{l}\text { J. Bonke } \\
\text { N. Datta Gupta } \\
\text { N. Smith }\end{array}$ & $\begin{array}{l}\text { Timing and Flexibility of Housework and Men } \\
\text { and Women's Wages }\end{array}$ & 5 & $08 / 03$ \\
\hline 861 & $\begin{array}{l}\text { Y. L'Horty } \\
\text { C. Rault }\end{array}$ & $\begin{array}{l}\text { Inflation, Minimum Wage and Other Wages: An } \\
\text { Econometric Study on French Macroeconomic } \\
\text { Data }\end{array}$ & 1 & $08 / 03$ \\
\hline
\end{tabular}

An updated list of IZA Discussion Papers is available on the center's homepage www.iza.org. 